\title{
20. MAGNETOBIOSTRATIGRAPHY OF PLANKTONIC FORAMINIFERAL DATUMS: DEEP SEA DRILLING PROJECT LEG 94, NORTH ATLANTIC ${ }^{1}$
}

\author{
P. P. E. Weaver, Institute of Oecanographic Sciences, Wormley, United Kingdom \\ and
}

B. M. Clement, Ocean Drilling Program, Texas A\&M University²

\begin{abstract}
The six Leg 94 sites have produced a unique data set from a north-south transect of sites, all with good paleomagnetic records, and all but one with above-average accumulation rates. We show that it is necessary to have high accumulation rates to obtain good quality magnetobiostratigraphies, and that it is difficult to correlate geological sequences over distances of several hundred kilometers without independent age control. Using the paleomagnetically derived ages for species ranges, we show several examples of diachronic first and last appearance datums between the core sites. This has enabled us to test the existing zonal schemes for the Pliocene-Pleistocene and to identify new zonal markers.
\end{abstract}

\section{INTRODUCTION}

There are still relatively few Neogene sites with good paleomagnetic control in the North Atlantic. Site 397 off northwestern Africa (Mazzei et al., 1979) has a good paleomagnetic record, and Berggren et al. (in press) used data from that site in their assessment of the ages of planktonic foraminiferal datums. More recently, Site 548 on the Goban Spur, southwest of Ireland, produced a good paleomagnetic record for the Quaternary and late Pliocene (Pujol and Duprat, 1985). Other paleomagnetically controlled datums in the North Atlantic have been derived mostly from piston cores (e.g., Saito et al., 1975; Haq et al., 1977). The six sites drilled on Leg 94 (Fig. 1) all have good paleomagnetic records through continuous Pliocene-Pleistocene sections (Clement and Robinson, this volume), and at all sites except Site 608 those sections accumulated at above average rates. These sites considerably extend our data base, and comparisons of species ranges with the magnetic stratigraphy have made possible not only the testing of existing zonations but also the recognition of new zonal markers.

The north-south transect of holes has made possible identification of species showing diachronic first and last appearance datums (FADs and LADs respectively), and has shown the latitudinal extent of some species. Comparison with the ages of the datums in other oceans shows that in some cases evolution was centered in one ocean, or one oceanographic province, with the new species subsequently migrating to other areas. The migratory first appearance of some species (e.g., Globorotalia puncticulata) was synchronic throughout the North Atlantic, and for other species (e.g., Globorotalia truncatulinoides) it was progressively later in higher latitudes. The data suggest that great care must be exercised in at-

\footnotetext{
${ }^{1}$ Ruddiman, W. F., Kidd, R. B., Thomas, E., et al., Init. Repts. DSDP, 94: Washington (U.S. Govt. Printing Office).

2 Addresses: (Weaver) Institute of Oceanographic Sciences, Brook Rd., Wormley, United Kingdom, (Clement) Ocean Drilling Program, Texas A\&M University, College Station, TX.
}

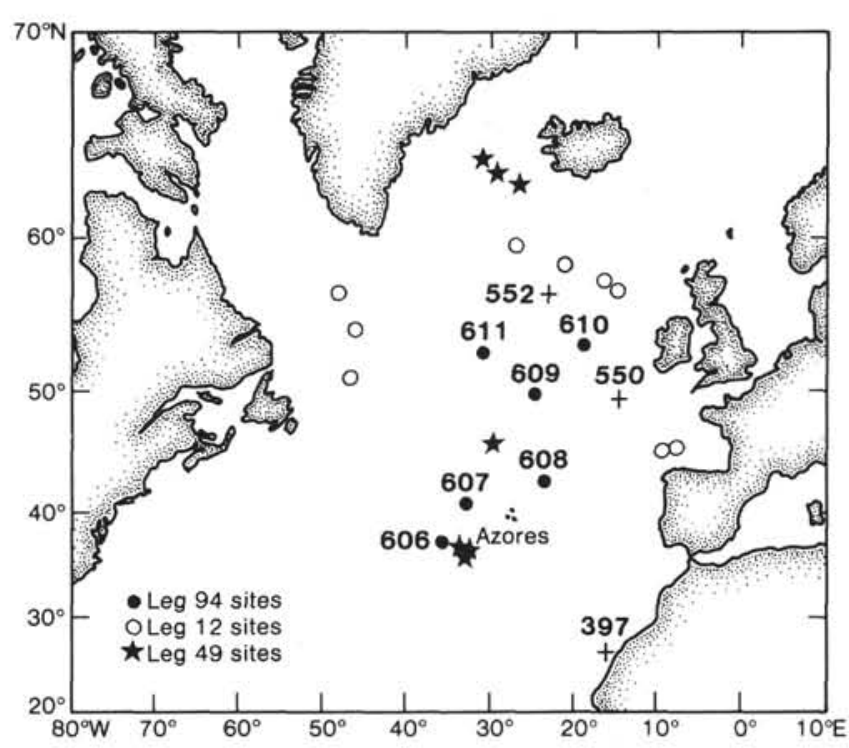

Figure 1. Locations of DSDP North Atlantic sites mentioned in the text.

tempting fine-scale stratigraphy using microfossils alone. Ideally, magnetobiostratigraphy should be carried out in all oceans at a variety of latitudes before species FADs and LADs are used in worldwide correlation. Far from diminishing the value of microfossils, this would lead to a greater understanding of evolution and migratory patterns.

Assessment of the ages of datums at all six sites has enabled us to test existing zonal schemes-particularly the PL zonation of Berggren $(1973,1977)$, which is the most widely used Pliocene zonation for the Atlantic. We have also identified several datum levels which give synchronic age determinations throughout the six sites studied (Weaver and Clement, in press), and we show how these fit within the PL zones. In this work we adopt the time scale of Berggren et al. (in press), and all ages have been calculated-or in the case of previously published 
data, recalculated-using this time scale. All the species discussed were figured by Weaver (this volume); see his work for full taxonomic details.

\section{ASSESSMENT OF PREVIOUS MAGNETOBIOSTRATIGRAPHIES}

Several papers have appeared in recent years comparing magnetic stratigraphies against planktonic foraminiferal ranges. Some of the more important papers covering the Pliocene are by Hays et al., 1969; Saito et al., 1975; Haq et al., 1977; Mazzei et al., 1979; Keigwin, 1982; and Poore et al., 1984. All of these authors have assumed a simple correlation between the first or last occurrence of a species and its position between two paleomagnetic boundaries. Thus, by using estimates of the ages of these paleomagnetic boundaries, ages of paleontological datums can be estimated. These estimates are often quoted to the nearest 10,000 yrs. Comparisons between different quoted ages are subject to several pitfalls, however, and may give rise to misleading conclusions. Estimates of the ages of paleomagnetic boundaries are under constant revision (e.g., LaBrecque et al., 1977; Mankinen and Dalrymple, 1979; Berggren et al., in press), so it is important to convert all data to one time scale before comparisons are made. It is essential to quote the source of the time scale used, and preferably the depths downcore to paleomagnetic and paleontologic datums, so that the relative positions of these datums can be compared. This information was not always presented in some of the earlier works on this subject.

To produce an age estimate for a paleontological datum, two assumptions must be made: that paleomagnetic reversals are not time-transgressive, and that the fossils have not been reworked. Although both assumptions may be regarded as reasonable in many cases, they are both subject to a degree of error which depends on the sedimentation rate (Figs. 2, 3). It is not certain at what depth below the sediment/water interface the remanent magnetization is locked in (Denham and Chave, 1982; Tucker, 1980; Otofuji and Sasjima, 1981). Because of bioturbation, the magnetic minerals will not remain stably oriented in the upper few centimeters of the sediment, so the remanence is most probably set at or below the mixed layer. Thus, a paleomagnetic boundary may be significantly younger than the sediment it lies in (Fig. 2). Watkins (1968) and Dymond (1969) recognized this phenomenon, and Watkins estimated that the mixing depth could be as much as $50 \mathrm{~cm}$. Ruddiman and Glover (1972), however, found ash layers in North Atlantic cores to be disseminated by bioturbation as much as $27 \mathrm{~cm}$ below (average of $14 \mathrm{~cm}$ below) the level of the original layer. Therefore, $50 \mathrm{~cm}$ may be an overestimate, and the paleomagnetic signal may be set between 0 and $30 \mathrm{~cm}$ below the sediment/water interface. The age of the sediment at the level at which the paleomagnetic signal is set depends on the sedimentation rate, and if this is very low, an appreciable discrepancy may develop between the true age of the paleomagnetic reversal and the age of the sediment in which it is measured. For a core with an average sedimentation rate of $2 \mathrm{~cm} / 1000$ yrs., the age at 20 and $30 \mathrm{~cm}$ depth would be 10,000 and 15,000 yrs., respectively (Fig. 3 ). Cores such as RC11 252 from the North Atlantic (Saito et al., 1975) and V24 59 from the Pacific (Hays et al., 1969) have been used for magnetobiostratigraphy even though they have very low sedimentation rates $(0.13$ and $0.27 \mathrm{~cm} / 1000$ yrs., respectively): every $10 \mathrm{~cm}$ depth in these cores represents 77,000 and 37,000 yrs. respectively. Errors in paleomagnetic ages can therefore exceed 100,000 yrs. in cores with very low deposition rates, and these errors can be compounded by fossil bioturbation.

Berger and Heath (1968) set up a model of vertical mixing in an attempt to predict the exact extinction level of a species. Their model, however, requires a homogeneously mixed layer with a sharp boundary to an unmixed layer beneath it, and also requires that the extinction be abrupt. Decreasing bioturbation with depth, and gradually declining species numbers before final extinction, would make the Berger and Heath model unworkable. Ruddiman and Glover (1972) measured the dissipation of ash layers in North Atlantic cores by mixing. As mentioned previously, the ash layers were spread downward an average of $14 \mathrm{~cm}$ (but a maximum of $27 \mathrm{~cm}$ ), and spread upward an average of $22 \mathrm{~cm}$ (maximum 44 $\mathrm{cm}$ ). Thus, species extinctions could appear at least 44 $\mathrm{cm}$ higher than their true level, and first appearances of species could be as much as $27 \mathrm{~cm}$ lower than their true levels (Fig. 2). In cores with average sedimentation rates of $2 \mathrm{~cm} / 1000 \mathrm{yrs}$., these depths correspond to 22,000 and 13,500 yrs., respectively, In core RC11 252 (average deposition rate of $0.13 \mathrm{~cm} / 1000 \mathrm{yrs}$.), the depths of 44 and $27 \mathrm{~cm}$ equate with 338,000 and 208,000 yrs., respectively (Fig. 3).

It is stressed that these calculations are based on Ruddiman and Glover's data, which represent only six cores, all from the North Atlantic. They therefore almost certainly do not represent the maximum levels to which bioturbation can occur, and they may not represent exactly the bioturbation pattern in other oceans. There are large differences between the maximum and minimum thicknesses of the mixed layers in Ruddiman and Glover's data, suggesting that it is not easy to model bioturbation.

The most desirable sediments for assessing the ages of datums are therefore those with the highest sedimentation rates. The error in the age of a LAD in a core with a very low deposition rate can be on the order of 100,000 yrs. or more, but the actual errors cannot be estimated.

Other errors can be introduced by sampling intervals, but these can be calculated. If the age of a datum is taken at the midpoint between two samples, the error will be, at maximum, half of the age difference between the samples. Using Figure 3, samples spaced $10 \mathrm{~cm}$ apart in core RC11 252 will be accurate to 37,000 yrs. Samples spaced $3 \mathrm{~m}$ apart in cores with $5 \mathrm{~cm} / 1000$ yrs. average sedimentation rate will be accurate to 30,000 yrs. Since Sites 606,607 , and 609 to 611 have deposition rates above $3.5 \mathrm{~cm} / 1000$ yrs., the error caused by sample spacing will be $0.04 \mathrm{~m}$.y. at maximum, and in most cores with average deposition rates of about $5 \mathrm{~cm} / 1000$ yrs. the maxi- 

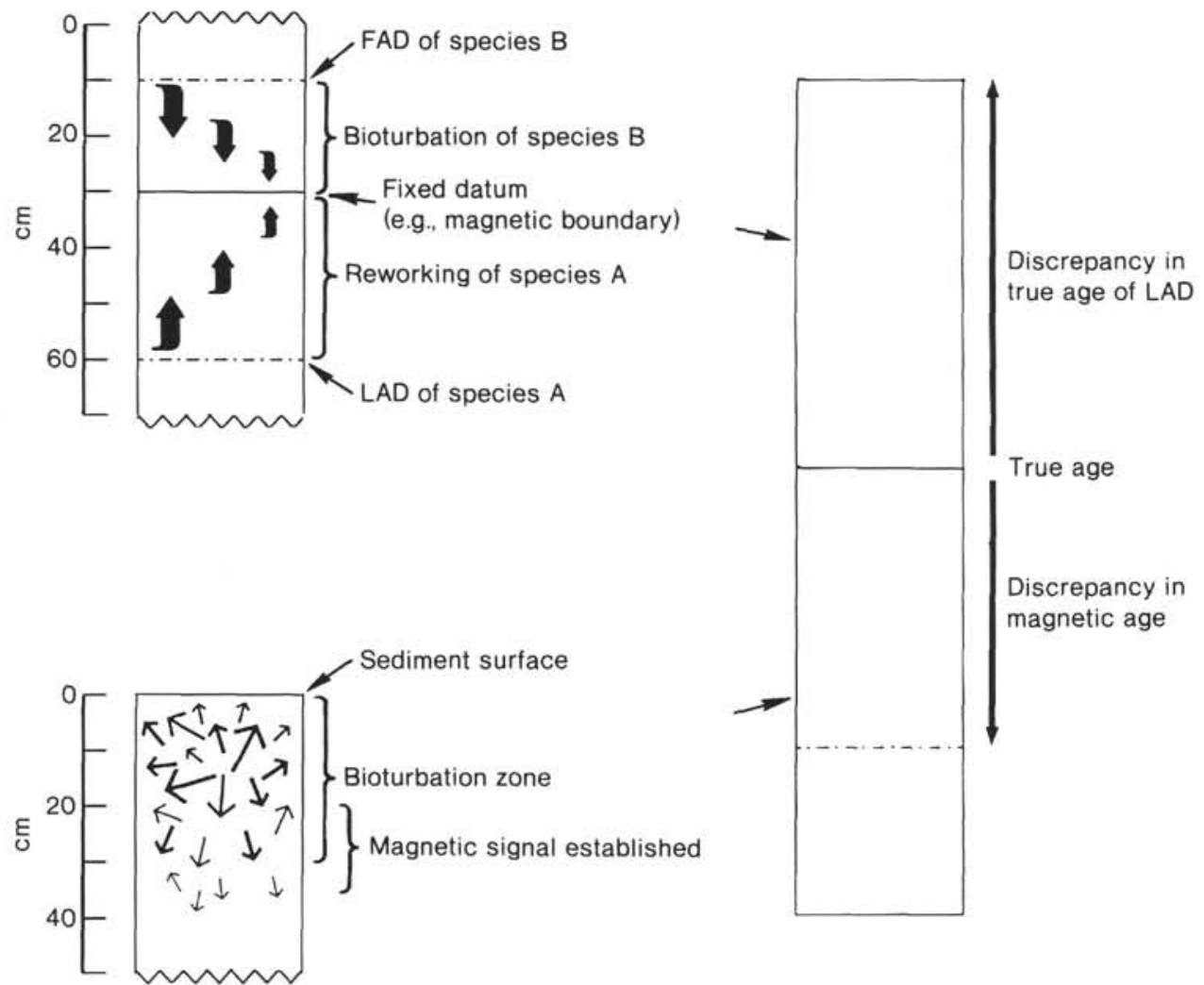

Figure 2. Effect of low deposition rate and bioturbation on determination of paleomagnetically derived ages of fossil datums.

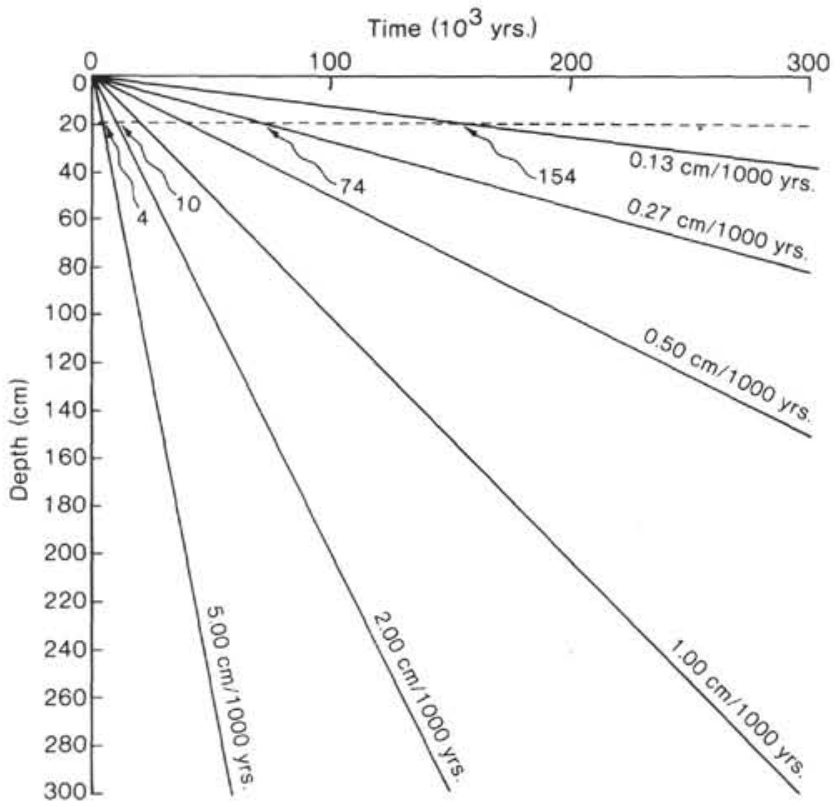

Figure 3. Age/depth plots of cores with varying deposition rates. Note the age discrepancy between a magnetic reversal and the sediment in which it lies if the bioturbated zone is $20 \mathrm{~cm}$ thick (indicated by wavy arrow for various sedimentation rates).

mum error will be 0.03 m.y. Errors due to bioturbation and delayed setting of the paleomagnetic signal will be minimal (less than 0.01 m.y.) in these cores because of the high deposition rates.

\section{SUBTROPICAL TEMPERATE ZONATIONS}

The most widely quoted Neogene planktonic foraminiferal zonation is that of Blow (1969). Several of Blow's zones are based on evolutionary lineages, some of which are very difficult to recognize, as pointed out by Kennett and Srinivasan (1983). Most of Blow's zonal species are restricted to tropical areas, so his zonation is not applicable to the North Atlantic sites covered in this study.

Subtropical/temperate zonations have been set up by Berggren $(1973,1977)$ and Kennett (1973) for the southwestern Pacific and by Cita (1973) for the Mediterranean. The stratigraphic ranges of species studied here have not been found to coincide with those in the southwestern Pacific-in general, species make their first appearances considerably later in the North Atlantic (see later). There is much less paleomagnetic control in the southwestern Pacific, so exact dates are difficult to estimate there. Cita (1973) subdivided the Mediterranean Pliocene into five zones. Of these, the three zones representing the late Pliocene are recognizable in the subtropical North Atlantic, but the subdivision of the early Pliocene based on the evolution of Globorotalia margaritae cannot be followed (Fig. 4). Cita's zones are directly tied to the paleomagnetic record at DSDP Site 132 in the Tyrrhenian Sea, which facilitates easy comparison with the Leg 94 sites.

The zonation of Berggren $(1973,1977)$ divides the Pliocene into six zones (PL1-PL6) and uses the Globorotalia truncatulinoides Zone (N22 of Blow, 1969) for the Pleistocene (Fig. 4). Berggren (1977) also subdivided 


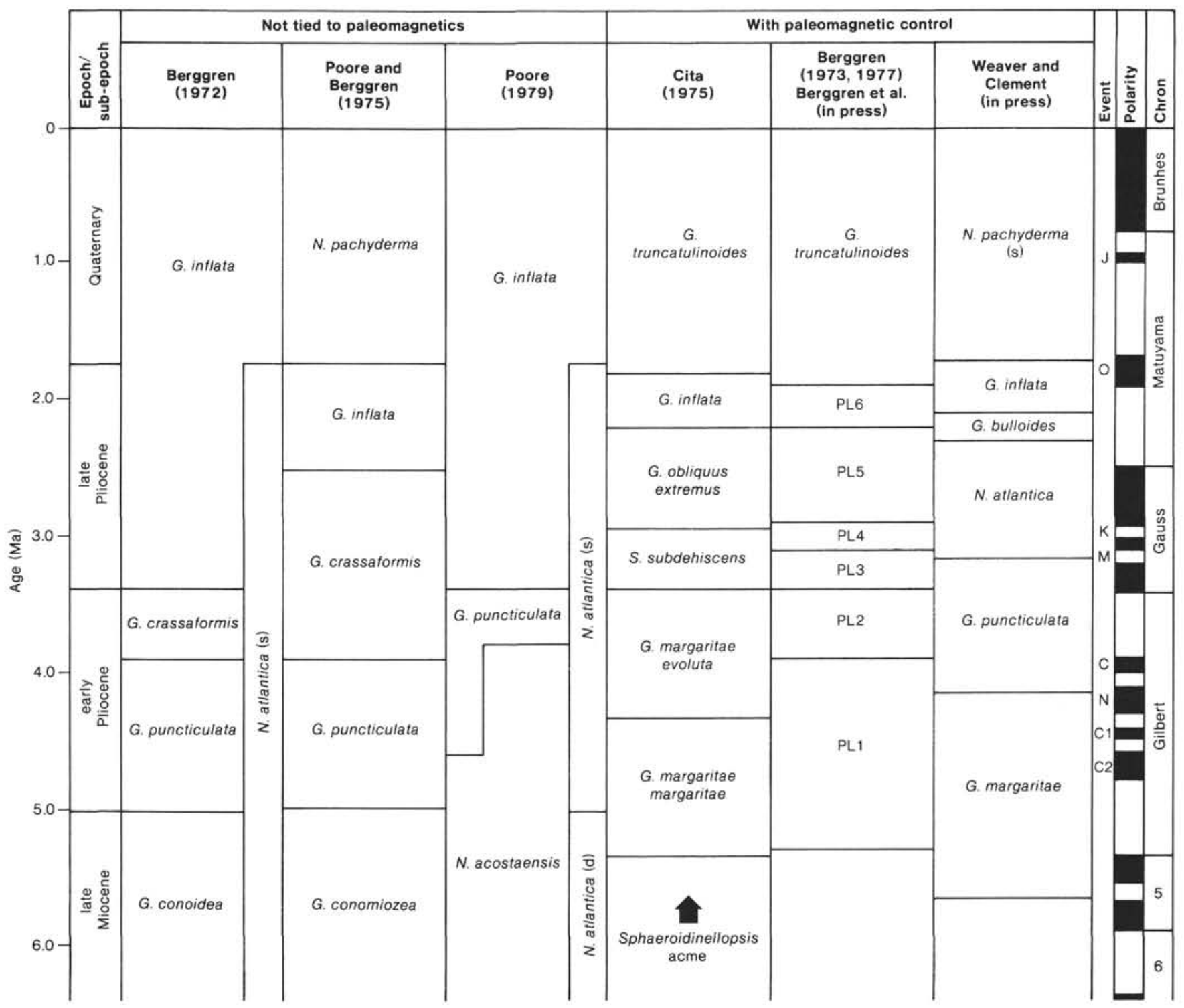

Figure 4. Zonal schemes for areas in and around the North Atlantic. Letter designations of magnetic events: $\mathrm{J}=\mathrm{Jaramillo}, \mathrm{O}=\mathrm{Olduvai}, \mathrm{K}=\mathrm{Kae}-$ na, $\mathrm{M}=$ Mammoth, $\mathrm{C}=$ Cochiti, $\mathrm{N}=$ Nunivak. $\mathrm{C} 1, \mathrm{C} 2=$ Chrons $\mathrm{C} 1, \mathrm{C} 2$.

the late Miocene into three zones, and Berggren et al. (1983) extended this zonation to 13 zones (M1-M13) for the Miocene. Berggren (1973) used the data of Hays et al. (1969) and Saito et al. (1975), together with unpublished data, to tie his datums to the paleomagnetic time scale. Berggren's latest estimates of the ages of the PL zonal markers can be found in Berggren et al (in press). We found that many of Berggren's zones can be readily identified at Sites 606 and 607, but at Site 608 some of the marker species are rare or absent, and at more northern Sites 609,610 , and 611 , only a few of the zones can be recognized.

\section{Sites 606 and 607}

These two sites lie in the northern part of the presentday subtropical gyre and show similar stratigraphic distributions of species (see also Baldauf et al., this volume, for Shaw plots). At both sites the zonation of Berggren $(1973,1977)$ can be applied, and the ages of datums quoted by Berggren et al. (in press) can be tested against the excellent paleomagnetic records (Figs. 5, 6, Table 1). All ages are based on the time scale of Berggren et al. (in press).

The first occurrence of G. truncatulinoides is at 1.85 $\mathrm{Ma}$, in the Olduvai event, very close to the age of 1.9 Ma suggested by Haq et al. (1977). Rare specimens of Globorotalia tosaensis, the ancestor of $G$. truncatulinoides, can be found in Core 606-7 together with G. truncatulinoides. This appears to be an evolutionary transition, but it is not so obvious at Site 607, where G. tosaensis is virtually absent. North of Site 607, the first occurrence of $G$. truncatulinoides represents a migrational rather than an evolutionary event (see discussion of Sites 610 and 611).

The LAD of Globorotalia miocenica (marker for the top of PL5) is recorded at Sites 606 and 607 between the base of the Olduvai event and the top of Matuyama, just below the base of the Reunion event at Site 606, at 


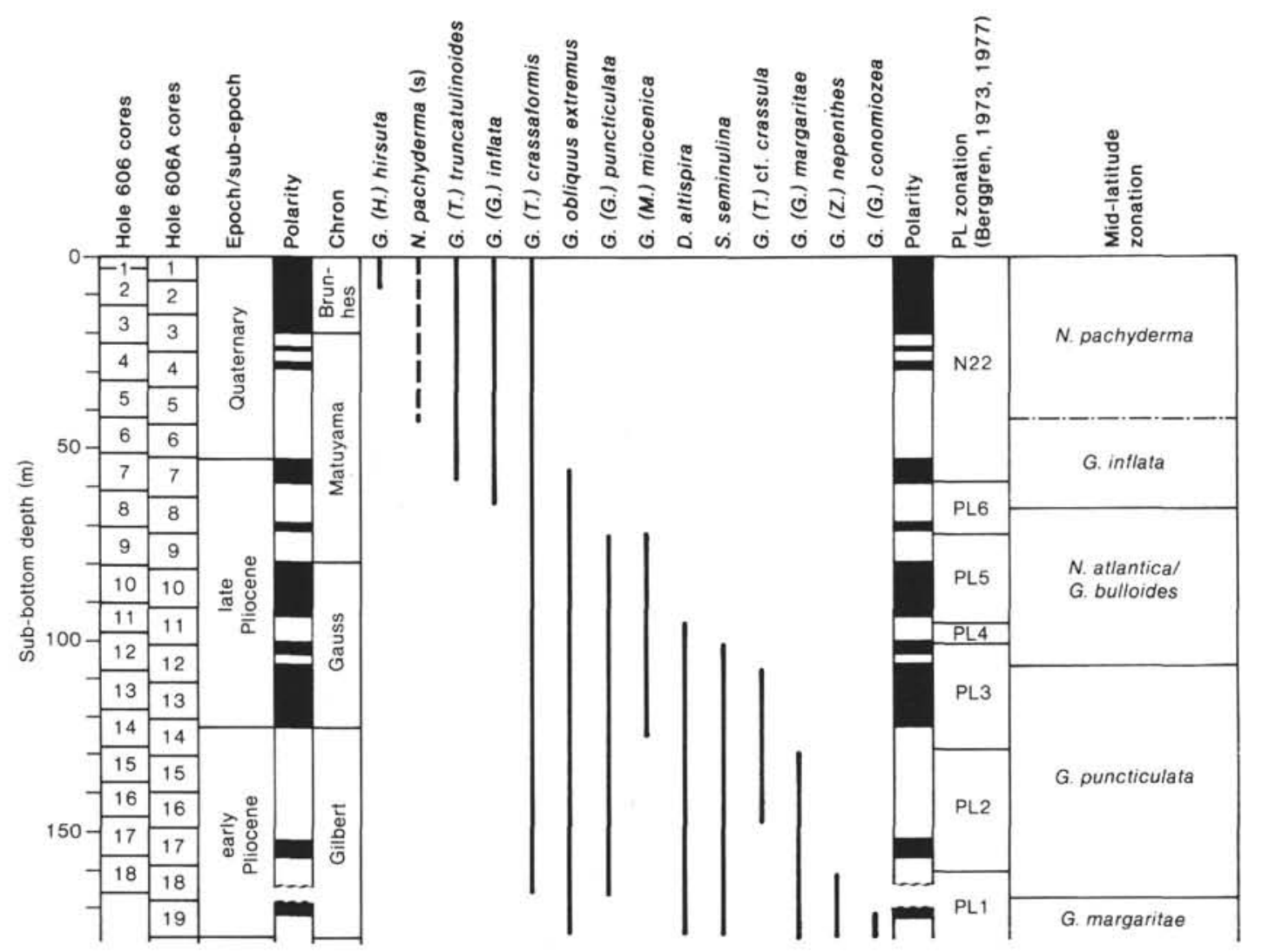

Figure 5. Magnetobiostratigraphy of Site 606. Mid-latitude zonation after Weaver and Clement (in press).

an estimated age of $2.27 \mathrm{Ma}$. This species does not occur at sites to the north of Site 607 . The age of its LAD is in good agreement with the estimated age of $2.2 \mathrm{Ma}$ given by Berggren et al. (in press), and lies between the estimated ages of 2.1 to 2.29 Ma given by Keigwin (1982) for Caribbean DSDP Site 502. Previously estimated ages of this datum in the North Atlantic are 2.0 Ma in core V16-205 (Saito et al., 1975) and 2.1 Ma at Site 397 (Mazzei et al., 1979).

Dentoglobigerina altispira has been found at Sites 606, 607, and 608. At Sites 606 and 607 it has its last occurrence in the Kaena event at an age of $2.94 \mathrm{Ma}$, whereas at Site 608 its last occurrence is just above the Kaena, at an age of $2.85 \mathrm{Ma}$. Other North Atlantic records of this species place its LAD in the Kaena event (e.g., Site 397, 2.98 Ma, Mazzei et al., 1979; Core RC11 252, $2.92 \mathrm{Ma}$, Saito et al., 1975). Keigwin found its LAD at $2.9 \mathrm{Ma}$ at Caribbean Site 502, and Hays et al. (1969) found its extinction a little below the Mammoth event in Indian Ocean core V20-163, and below the Mammoth event in equatorial Pacific core V24-59.

Berggren et al. (in press) recorded the extinction of Sphaeroidinellopsis seminulina $(=S$. subdehiscens in their terminology) at the top of the Mammoth event. At Site 606 the extinction of this species occurs at the base of the Kaena event $(2.98 \mathrm{Ma})$, and at Site 607 between the base of Kaena event and the top of the Mammoth event (3.02 Ma). Keigwin (1982) recorded this event between the Kaena and Mammoth events, and Saito et al. (1975) recorded it at the top of the Mammoth. However, core RC11 252 of Saito et al. has a very low deposition rate, so their sample spacing would allow the extinction of $S$. seminulina to lie between the base of the Kaena and the top of the Mammoth. Mazzei et al. (1979) recorded this extinction at the base of the Kaena event off northwestern Africa, and Cita (1975) recorded it within the Kaena event in the Mediterranean. Rio et al. (1984) recorded an extinction for this species at $3.05 \mathrm{Ma}$, just below the Kaena in Sicily. It therefore appears that the estimate of the age of this datum by Berggren et al. (in press) is a little old, and that its true LAD in the Atlantic and Mediterranean is at the base of the Kaena event at $3.0 \mathrm{Ma}$.

The LAD of $G$. margaritae has been widely used to mark the early/late Pliocene boundary at approximately the Gauss/Gilbert magnetic boundary. This datum has, however, been found to be time-transgressive at the six Leg 94 sites. There is even a difference between Sites 606 and 607; its last occurrence corresponds to an estimated $3.5 \mathrm{Ma}$ at Site 606 and $3.66 \mathrm{Ma}$ at Site 607 . The coincidence of this LAD with the Gauss/Gilbert magnetic boundary appears to be confined to tropical and Mediterranean regions (equatorial Pacific, Ryan et al., 1974; Indian Ocean, Saito et al., 1975; Atlantic, Mazzei et al., 1979; Mediterranean, Ryan, 1973). Outside the tropics, Poore et al. (1984) recorded the LAD of $G$. margaritae in the Gilbert Chron, at 3.8 Ma, in the South Atlantic, and Keller (1979) estimated, without the aid of paleomagnetic control, a last occurrence as old as $3.93 \mathrm{Ma}$ at Site 310 in the North Pacific. One tropical site also show- 


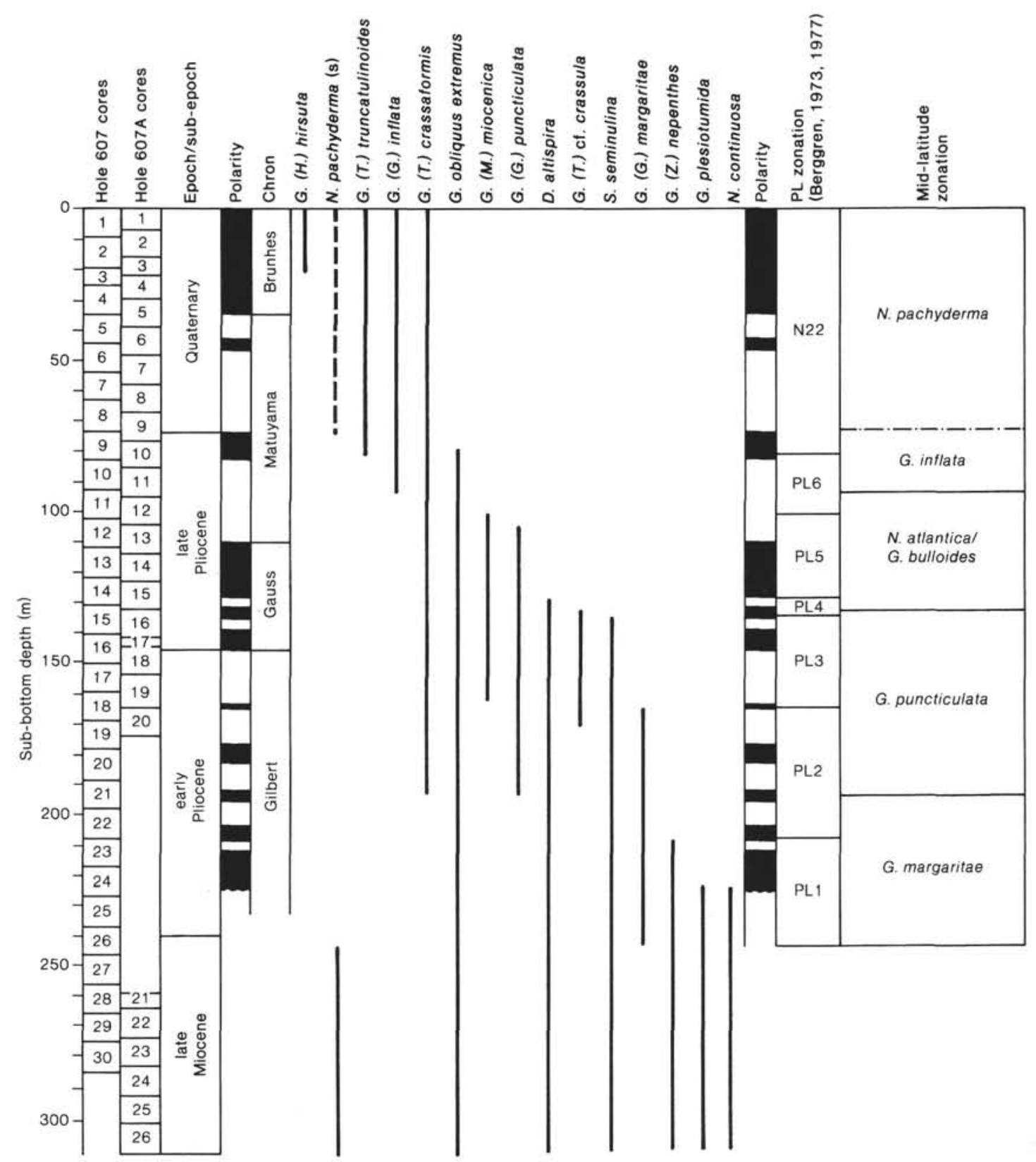

Figure 6. Ranges of selected species of planktonic foraminifers and magnetostratigraphy of Site 607. Depth scale applied to Hole 606; depths in Hole 606A adjusted after correlation of paleomagnetic datums to Hole 606 .

ing an early extinction of this species is Site 502 in the Caribbean (Keigwin, 1982), where it occurred at 3.6 Ma.

The LAD of Globigerina nepenthes, marking the base of Zone PL2, is also diachronic between Sites 606 and 607. At Site 606 it has its last occurrence at a level corresponding to $4 \mathrm{Ma}$, just beneath the base of the Cochiti event, whereas at Site 607 it has its last occurrence within the $\mathrm{Cl}$ event at $4.47 \mathrm{Ma}$. Thus, there is a nearly 0.5 $\mathrm{m} . \mathrm{y}$. difference in the age of this datum between two relatively close sites, both in the northern part of today's subtropical gyre. Saito et al. (1975) recorded the LAD of $G$. nepenthes at the top of the Cochiti event in both the Indian Ocean and subtropical North Atlantic, and Poore et al. (1984) recorded it only a little lower, within the Cochiti event, in the subtropical South Atlantic. Maz- zei et al., however, recorded the last occurrence of $G$. nepenthes beneath the Nunivak event, at $4.3 \mathrm{Ma}$, off northwestern Africa.

The base of the PL1 Zone is defined by the LAD of Globoquadrina dehiscens (Berggren 1973, 1977), and this is taken to mark the Miocene/Pliocene boundary at the base of the Gilbert Chron (Berggren, 1973; Saito et al., 1975). Unfortunately, $G$. dehiscens is virtually absent in the upper Miocene of the Leg 94 sites, and the base of Zone PL1 cannot be recognized on the basis of planktonic foraminifers.

Berggren et al. (1983) published a subdivision of the Miocene in which four zones (M10-M13) covered the late Miocene; these are based on the sequential FADs of Neogloboquadrina acostaensis, Globorotalia conomio- 
Table 1. Ages (Ma) of planktonic foraminiferal datums at Leg 94 sites (calculated from age/depth curves based on paleomagnetic data).

\begin{tabular}{|c|c|c|c|c|c|c|}
\hline \multirow[b]{2}{*}{ Zonal markers } & \multicolumn{6}{|c|}{ Site } \\
\hline & 606 & 607 & 608 & 609 & 610 & 611 \\
\hline \multicolumn{7}{|l|}{ PL zonal markers } \\
\hline G. truncatulinoides & 1.85 & 1.85 & $1.45-1.50$ & 1.84 & 1.8 & 1.35 \\
\hline FAD & (58) & $(81)$ & $(37-40 ; A 41-50)$ & (129) & (A96) & (47) \\
\hline $\begin{array}{l}\text { G. obliquus extremus } \\
\text { LAD }\end{array}$ & $\begin{array}{c}1.62-1.75 \\
(52-55 ; \mathrm{A} 63-73)\end{array}$ & $\begin{array}{c}1.76-1.90 \\
(77-83 ; \mathrm{A} 107-117)\end{array}$ & $\begin{array}{c}1.16-1.40 \\
(55-59 ; \mathrm{A} 31-41)\end{array}$ & $\begin{array}{l}1.65-1.70 \\
(123-126)\end{array}$ & $\mathrm{N} / \mathrm{P}$ & N/P \\
\hline $\begin{array}{l}\text { G. miocenica } \\
\text { LAD }\end{array}$ & $\begin{array}{c}2.26-2.28 \\
(71-74 ; \mathrm{A} 63-73)\end{array}$ & $\begin{array}{c}2.20-2.32 \\
(100-102 ; \mathrm{A} 98-107)\end{array}$ & $\mathrm{N} / \mathrm{P}$ & $\mathrm{N} / \mathrm{P}$ & N/P & N/P \\
\hline $\begin{array}{l}\text { G. altispira } \\
\text { LAD }\end{array}$ & $\begin{array}{c}2.93-2.96 \\
\text { (93-96; A92-102) }\end{array}$ & $\begin{array}{c}2.94-2.99 \\
(128-131 ; \mathrm{A} 126-136)\end{array}$ & $\begin{array}{l}2.80-2.90 \\
(93-94)\end{array}$ & N/P & $\mathrm{N} / \mathrm{P}$ & N/P \\
\hline $\begin{array}{l}\text { G. seminulina } \\
\text { LAD }\end{array}$ & $\begin{array}{c}2.98 \\
(100-103 ; \mathrm{A} 92-102)\end{array}$ & $\begin{array}{c}3.00-3.04 \\
(132-135 ; \mathrm{A} 136-146)\end{array}$ & $\begin{array}{c}2.90-3.00 \\
(94-97 ; \text { A } 89-99)\end{array}$ & N/P & $\mathrm{N} / \mathrm{P}$ & N/P \\
\hline G. margaritae & 3.48-3.50 & 3.66 & Hiatus & $4.13-4.17$ & $4.48-4.60$ & $3.82-3.84$ \\
\hline LAD & $(127-129 ; \mathrm{A} 121-130)$ & (164-167; A159-164) & (123-126; Al19-122) & (266-269; B259-268) & (A199-201) & (C204-206) \\
\hline G. nepenthes & $3.96-4.02$ & $4.45-4.50$ & Hiatus & $4.48-4.53$ & N/P & $4.65-4.70$ \\
\hline LAD & (A160-162) & $(205-208)$ & $(123-126)$ & (282-284; B278-287) & & (C259-262) \\
\hline \multicolumn{7}{|l|}{ New zonal markers } \\
\hline N. pachyderma (s) & Rare & Rare & $0.80-0.92$ & 1.7 & 1.66 & 1.77 \\
\hline FAD & & & $(17-26 ; A 12-22)$ & (121) & (A93) & $(63 ; C 80-89)$ \\
\hline G. inflata & $2.01-2.06$ & $2.04-2.16$ & 1.90 & $2.12-2.18$ & $2.00-2.04$ & $2.10-2.26$ \\
\hline FAD & $(62-65 ; A 63-73)$ & (92-97; A88-98) & (45-46; A41-50) & (150-160; B143-153) & (A105-106) & $(87-97 ; \mathrm{C} 100-108)$ \\
\hline N. atlantica & N/P & $\mathrm{N} / \mathrm{P}$ & $2.05-2.10$ & $2.30-2.36$ & $2.28-2.30$ & $2.26-2.30$ \\
\hline LAD & & & (59-62; A70-79) & (161-170; B153-164) & (A118-119) & $(97-107 ; \mathrm{C} 108-111)$ \\
\hline G. cf. crassula & $3.16-3.21$ & 3.00 & $2.80-2.90$ & $3.11-3.25$ & $3.17-3.63$ & $3.10-3.25$ \\
\hline LAD & $(106-108 ; \mathrm{A} 102-111)$ & $(131-132 ; \mathrm{A} 136-146)$ & (91-93; A79-89) & $(237-240 ;$ B $230-240)$ & (A163-172) & (C156-166) \\
\hline G. puncticulata & 4.16 & $4.06-4.30$ & Hiatus & $4.13-4.17$ & $\mathrm{~N} / \mathrm{S}$ & $4.12-4.18$ \\
\hline FAD & (156-166; A166-169) & $(188-198)$ & $(123-126 ; \mathrm{A} 137-146)$ & (262-266; B268-278) & & (C225-228) \\
\hline N. pachyderma (s-d) & Not cored & $\begin{array}{l}5.04-5.12 \\
(239-244)\end{array}$ & $\begin{array}{c}\text { Hiatus } \\
(126-132)\end{array}$ & $5.08-5.15$ & $\mathrm{~N} / \mathrm{S}$ & $4.70-4.84$ \\
\hline & Not cored & $\begin{array}{l}(239-244) \\
5.58-5.71\end{array}$ & (126-132) & (294-323) & & (C262-272) \\
\hline $\begin{array}{l}\text { G. margaritae } \\
\text { FAD }\end{array}$ & Not cored & $\begin{array}{l}5.58-5.71 \\
(239-244)\end{array}$ & $\begin{array}{l}5.30-5.40 \\
(132-133)\end{array}$ & $\begin{array}{c}5.50-5.68 \\
(342-351 ; \mathrm{B} 326-336)\end{array}$ & $\mathrm{N} / \mathrm{S}$ & $\begin{array}{c}5.28-5.44 \\
(C 300-310)\end{array}$ \\
\hline N. atlantica (s-d) & Not cored & $\mathrm{N} / \mathrm{P}$ & $\mathrm{N} / \mathrm{P}$ & $\begin{array}{l}6.15-6.75 \\
(371-399)\end{array}$ & $\begin{array}{c}6.58-6.82 \\
(\mathrm{E} 289-299)\end{array}$ & $\begin{array}{c}6.84-7.24 \\
(\mathrm{C} 386-396)\end{array}$ \\
\hline
\end{tabular}

Note: $\mathrm{FAD}=$ first appearance datum; $\mathrm{LAD}=$ last appearance datum; N/P $=$ not present; $\mathrm{N} / \mathrm{S}=$ not sampled. Data in parentheses $=$ depth of datum $(\mathrm{m}) ;$ letters identify hole number if not first hole drilled at site (no letter).

$z e a$, and $G$. margaritae. The FAD of $G$. margaritae occurs in an interval where no magnetic record was identified at Site 607 (Holes 606 and 606A did not penetrate this deep), but extrapolation of the sedimentation rate curve gives an estimated age of 5.6 to $5.7 \mathrm{Ma}$ for the FAD of $G$. margaritae at Site 607 . This compares well with the estimated age of $5.6 \mathrm{Ma}$ for this datum given by Berggren et al. (in press).

Berggren's zonation is therefore reliable for the late Pliocene, but his early Pliocene datums (LADs of $G$. margaritae and $G$. nepenthes) are diachronic, even over short distances. Several other datums are of value in Pliocene stratigraphy, however, and some of these can be identified at all Leg 94 sites. The replacement of Globorotalia puncticulata by Globorotalia inflata occurred much later in the North Atlantic than in the southwestern Pacific. Malmgren and Kennett (1982) showed a transition between these two species at $2.9 \mathrm{Ma}$ in the southwestern Pacific, whereas in the North Atlantic the first appearance of $G$. inflata was at $2.1 \mathrm{Ma}$, and thus may have been a migrational event. There is invariably a short interval between the LAD of $G$. puncticulata and the FAD of $G$. inflata in which neither species is present. The FAD of $G$. inflata, however, has the same age at all Leg 94 sites, and is therefore reliable for the North Atlantic. A comparable age of $2.26 \mathrm{Ma}$ was recorded for this da- tum in the Mediterranean (Ryan, 1973), and Rio et al. (1984) recorded the FAD of $G$. inflata at $2.05 \mathrm{Ma}$ in Sicily.

A species closely related to the Globorotalia crassula group, called $G$. cf. crassula, has been identified (Weaver, this volume) as occurring at about the lower/upper Pliocene boundary. A taxonomic appraisal of this species is currently in progress. The species is present at all Leg 94 sites, and its LAD is a reliable datum, occurring in or just below the Mammoth event, between 3.0 and 3.2 Ma (Table 1).

The FAD of $G$. puncticulata has been used by several authors as a useful early Pliocene datum (e.g., Berggren, 1972; Poore, 1979; Kennett and Watkins, 1974). Berggren (1972) took its FAD in the North Atlantic to approximate the Miocene/Pliocene boundary, and Poore (1979) suggested a FAD just above this boundary. We estimate this datum to lie in the Nunivak event of the Gilbert Chron, at $4.16 \mathrm{Ma}$. It is a reliable datum at all the Leg 94 sites. A similar age for this datum was estimated by Kennett and Watkins (1974) in the Mangapoike River section in New Zealand. Other estimates of the FAD of G. puncticulata suggest a greater age, $4.4 \mathrm{Ma}$, for example, on the Rio Grande Rise (Berggren et al., 1983), and 4.32 Ma off northwestern Africa (Mazzei et al., 1979), and a lesser age of 3.3 to $3.4 \mathrm{Ma}$ in the Caribbean (Keig- 
win, 1982). Kennett and Srinivasan (1983) have suggested that G. puncticulata evolved from Globorotalia sphericomiozea Walters, whereas Berggren (1977) suggested an evolution from Globorotalia cibaoensis Bermudez. Neither species is common in the North Atlantic, and no evolution of G. puncticulata can be traced. The North Atlantic FAD is therefore probably migrational, which would account for its slightly lesser age. Thus, the FAD of $G$. puncticulata may not be ubiquitously useful, but we believe it to be reliable in the mid- to high-latitude North Atlantic.

\section{Sites 609, 610, and 611}

These sites lie under present-day temperate to cool temperate water-mass areas, so the subtropical zonation of Berggren $(1973,1977)$ cannot be applied. A new midto high-latitude zonation for the North Atlantic, based on the Leg 94 cores, has been produced by Weaver and Clement (in press) (Fig. 4).

Species from the PL zonation which are present at Sites 609 to 611 cannot be relied on for stratigraphy (Figs. 7-9, Table 1; see also Baldauf et al., this volume). Globorotalia truncatulinoides has a FAD at $1.84 \mathrm{Ma}$ at Site $609,1.8 \mathrm{Ma}$ at Site 610, and 1.35 Ma at Site 611. At none of these sites was $G$. tosaensis found, and the FAD of $G$. truncatulinoides therefore represents a migrational event. We agree with Kennett's (1968) conclusion that G. truncatulinoides evolved in tropical/subtropical areas and migrated into cooler waters later. After its first appearance, $G$. truncatulinoides is not continuously present at Sites 609,610 , and 611 . This is not simply related to cool climatic conditions, since the species is more likely to be absent in the lower part of its range corresponding to a time when the climate was relatively warm. The sporadic distribution of this species makes it unreliable as a zonal marker north of about $45^{\circ} \mathrm{N}$.

Diachronic LADs were found for $G$. margaritae and $G$. nepenthes; these LADs are very unreliable datums. The age of the LAD of $G$. margaritae varies from 3.5 $\mathrm{Ma}$ at Site 606 to $4.5-4.6 \mathrm{Ma}$ at Site 610 -a variation of over 1 m.y. across $16^{\circ}$ of latitude. Poore et al. (1984) recorded an age of $3.8 \mathrm{Ma}$ for this datum in the South Atlantic, but Keller (1979) estimated an age of $3.93 \mathrm{Ma}$ (without paleomagnetic control) at Site 310 in the North Pacific. This datum has previously been used to mark the early/late Pliocene boundary (Berggren et al., in press), but its usefulness seems to be restricted to tropical areas.

The LAD of $G$. nepenthes also shows a significant age difference between Sites 606 (4 Ma) and 607 (4.5 Ma), but its LAD does not become much older at Sites 609 $(4.5 \mathrm{Ma})$ and $611(4.67 \mathrm{Ma})$. Berggren et al. (in press) estimate the age of this datum at $3.9 \mathrm{Ma}$, but again this may be a useful datum only in tropical regions.

The datums defined by Weaver and Clement (in press) have been chosen for their synchrony between Sites 609 to 611, but some of them can also be identified at Sites 606 and 607 (Fig. 13). (See also Baldauf et al., this volume). The FAD of sinistral, encrusted Neogloboquadrina pachyderma - a cold-water morphotype-is readily recognizable at Sites 609 to 611 because this morpho- type is generally present in large numbers throughout its range. It can be found at Sites 606 and 607, but only in cool intervals and then rarely. Its usefulness as a datum is therefore limited south of $50^{\circ} \mathrm{N}$. It first appears at about $1.7 \mathrm{Ma}$ at Sites 609 to 611 and continues to the top of the section (present) (Table 1; Fig. 13).

The FAD of $G$. inflata is a reliable datum, occurring at about $2.1 \mathrm{Ma}$, between the base of the Olduvai event and the base of the Matuyama Chron at all sites. The LAD of Neogloboquadrina atlantica is an important datum at Sites 609 to 611 , because this species is common right up to its disappearance. Its LAD occurs just above the base of the Matuyama Chron, at $2.3 \mathrm{Ma}$, and has also been identified at Sites 548 and 552 on the Goban Spur (Pujol and Duprat, 1985) and in the Rockall area (Huddlestun, 1984). In the absence of paleomagnetic data, Berggren (1972) and Poore (1979) used this datum to recognize the Pliocene/Pleistocene boundary at DSDP Leg 12 sites and Leg 49 sites, respectively. Immediately below the LAD of $N$. atlantica there is a large increase in its abundance (Hooper and Funnell, in press). This increase corresponds to the onset of Northern Hemisphere glaciation at about $2.4 \mathrm{Ma}$, when $N$. atlantica not only increased in abundance but also spread southward (Hooper and Weaver, in press). It is recorded both at Site 608 (Weaver, this volume) and in the Mediterranean (Spaak, 1983) for a limited interval before its extinction. In this short interval between the LAD of $N$. atlantica and the FAD of $G$. inflata there are increased relative abundances of Globigerina bulloides and N. pachyderma (d); the interval is named the G. bulloides Zone (Weaver and Clement, in press).

Below the LAD of $N$. atlantica there is a long concurrent range of $N$. atlantica and G. puncticulata. This interval can be subdivided by the LAD of Globorotalia cf. crassula, which occurs in, or just below, the Mammoth event, between 3.0 and $3.2 \mathrm{Ma}$. This species is generally common throughout its range, and provides a reliable datum despite its uncertain taxonomic position (Weaver, this volume).

The FAD of G. puncticulata occurs in the Nunivak event of the Gilbert Chron, at an estimated age of 4.16 $\mathrm{Ma}$. This is younger than the age of $4.5 \mathrm{Ma}$ derived both by Berggren et al. (in press), from Rio Grande Rise data, and by Malmgren and Kennett (1982), from South Pacific data. These authors suggest different evolutionary origins for G. puncticulata: from Globorotalia sphericomiozea in the South Pacific and from Globorotalia cibaoensis in the South Atlantic (Berggren, 1977). Both these possible ancestors are rare or poorly developed in the North Atlantic, and this datum may therefore represent a migrational event. It is nevertheless a synchronic datum at all six Leg 94 sites, and thus links the highand low-latitude zonations.

The usefulness of the FAD of $G$. margaritae at Site 607 has been mentioned. This datum can be recognized at Sites 609 and 611 in the upper part of Chron 5. G. margaritae is much rarer at the northern Sites 610 and 611 , particularly in the lower part of its range, and was not recorded at Sites 407 and 408 (Poore, 1979). Its usefulness is therefore limited north of about $50^{\circ} \mathrm{N}$. 


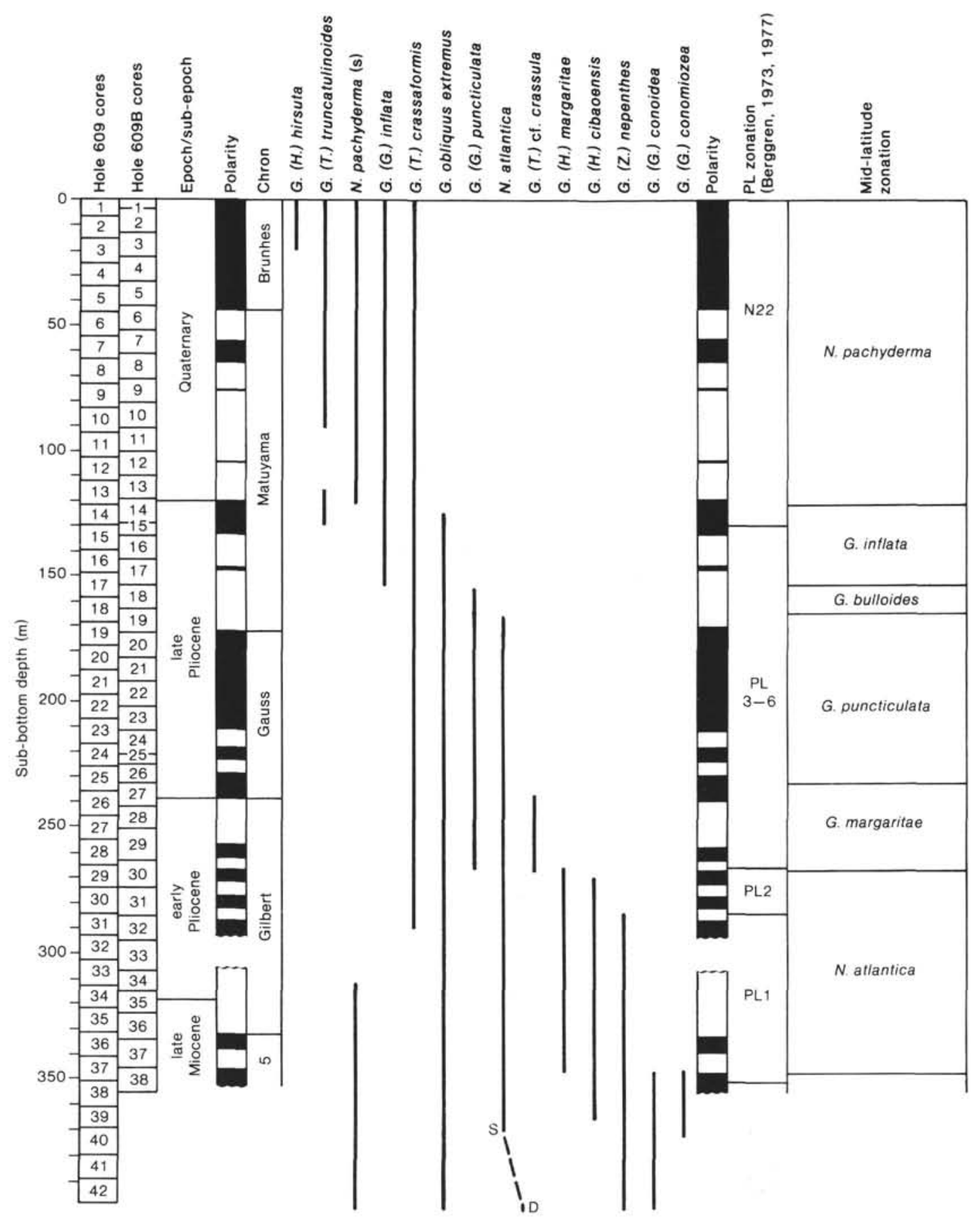

Figure 7. Ranges of selected species of planktonic foraminifers and magnetostratigraphy of Site 609. Depth scale applies to Hole 609; depths in Hole 609B have been adjusted after correlation of paleomagnetic datums to Hole 609.

The FAD of $G$. conomiozea marks the base of the M12 Zone of Berggren et al. (1983). This species, however, has a very patchy distribution in the North Atlantic. Berggren (1984, fig. 2) suggests that its geographic range extends south to include DSDP Site 334 , at $37^{\circ} \mathrm{N}$. It was not recorded, however, by Miles (1977) in his account of this site, and it does not occur at Site $607\left(41^{\circ} \mathrm{N}\right)$. The two sites with the most common occurrences of this species are Site 608 , at $43^{\circ} \mathrm{N}$, and Site 410 (Poore, 1979), at $45^{\circ} \mathrm{N}$. G. conomiozea may be common at Site 610 , where it was found in Cores $610 \mathrm{E}-1$ and $610 \mathrm{E}-2$, at the top of the Miocene, but in Hole 610 it was presumably missed by spot coring (Weaver, this volume). Poore and Berggren (1975) recorded $G$. conomiozea at Site 116, but it was very rare at Sites 407 and 408 (Poore, 1979) and was not common at Site 611. Berggren et al. (in press) estimate the age of the FAD of G. conomiozea at 6.5 Ma. This compares well with the first appearances between 6.48 and $6.58 \mathrm{Ma}$ at Site 610 and between 6.28 and $6.46 \mathrm{Ma}$ at Site 611 . At Site 609 it first appeared between 6.05 and $6.2 \mathrm{Ma}$, and at Site 608 between 6.5 and $7.0 \mathrm{Ma}$. 


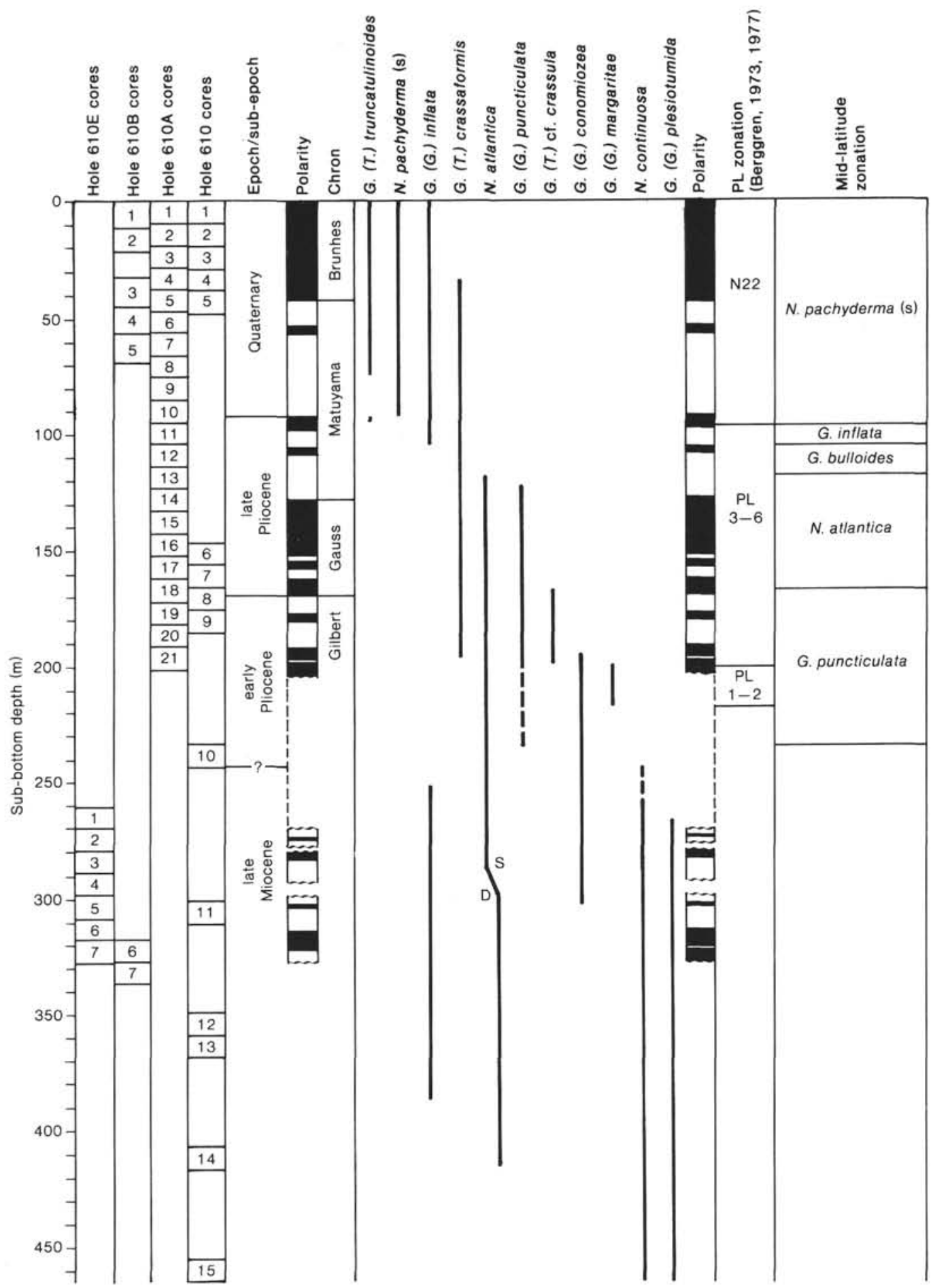

Figure 8. Ranges of selected species of planktonic foraminifers and magnetostratigraphy of Site 610. Depth scale refers to Holes $610,610 \mathrm{~A}$, and $610 \mathrm{E}$; depths in Hole 610D have been adjusted after correlation of paleomagnetic datums to Hole 610A.

There are relatively few planktonic foraminiferal datums in the upper Miocene (particularly in the higher latitudes), and the only reliable datum may be a coiling direction change in $N$. atlantica. This datum was used by Poore (1979) to recognize the Miocene/Pliocene boundary, although Berggren (1972) had recorded it in the lower part of the upper Miocene. This coiling direction change occurred between 6.75 and $6.85 \mathrm{Ma}$ at Sites 609 , 610 , and 611 .

\section{Site 608}

This site lies between the subtropical Sites 606 and 607 to the south and the temperate/subpolar Sites 609 to 611 to the north. At this location elements of both 


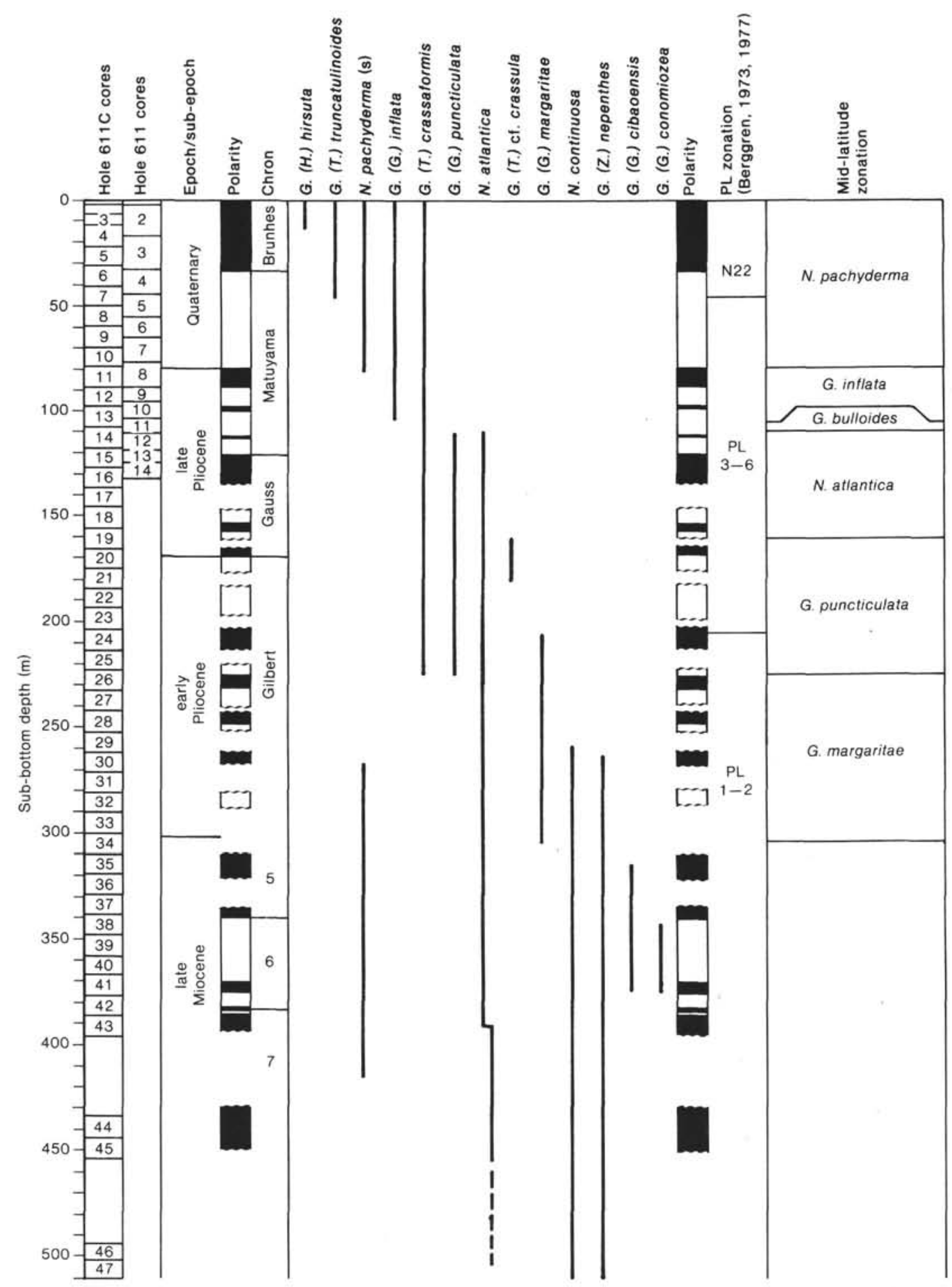

Figure 9. Ranges of selected species of planktonic foraminifers and magnetostratigraphy of Site 611. Depth scale refers to Hole 611C; depths in Hole 611 have been adjusted after correlation of paleomagnetic datums to Hole 611C.

the southern and northern zonations were found (Figs. $10,11)$. This site had an average deposition rate of 2 to $3 \mathrm{~cm} / 1000$ yrs. during the late Miocene to Recent, somewhat less than the rate at the other sites. Some disturbances occurring in the paleomagnetic record of the Pliocene and late Miocene suggest sediment slumping or redistribution. Many of the paleomagnetically dated FADs and LADs at this site do not correlate well with those at the other sites. This may be due partly to its location, at the extremity of the geographic ranges of both cold- and warm-water species, or to sediment instability in the area (reworking).

The correlation of datums with the paleomagnetic record through the Matuyama shows serious discrepancies in comparison with the other sites. The paleomagnetic record itself is ambiguous (Fig. 10), with two possible 


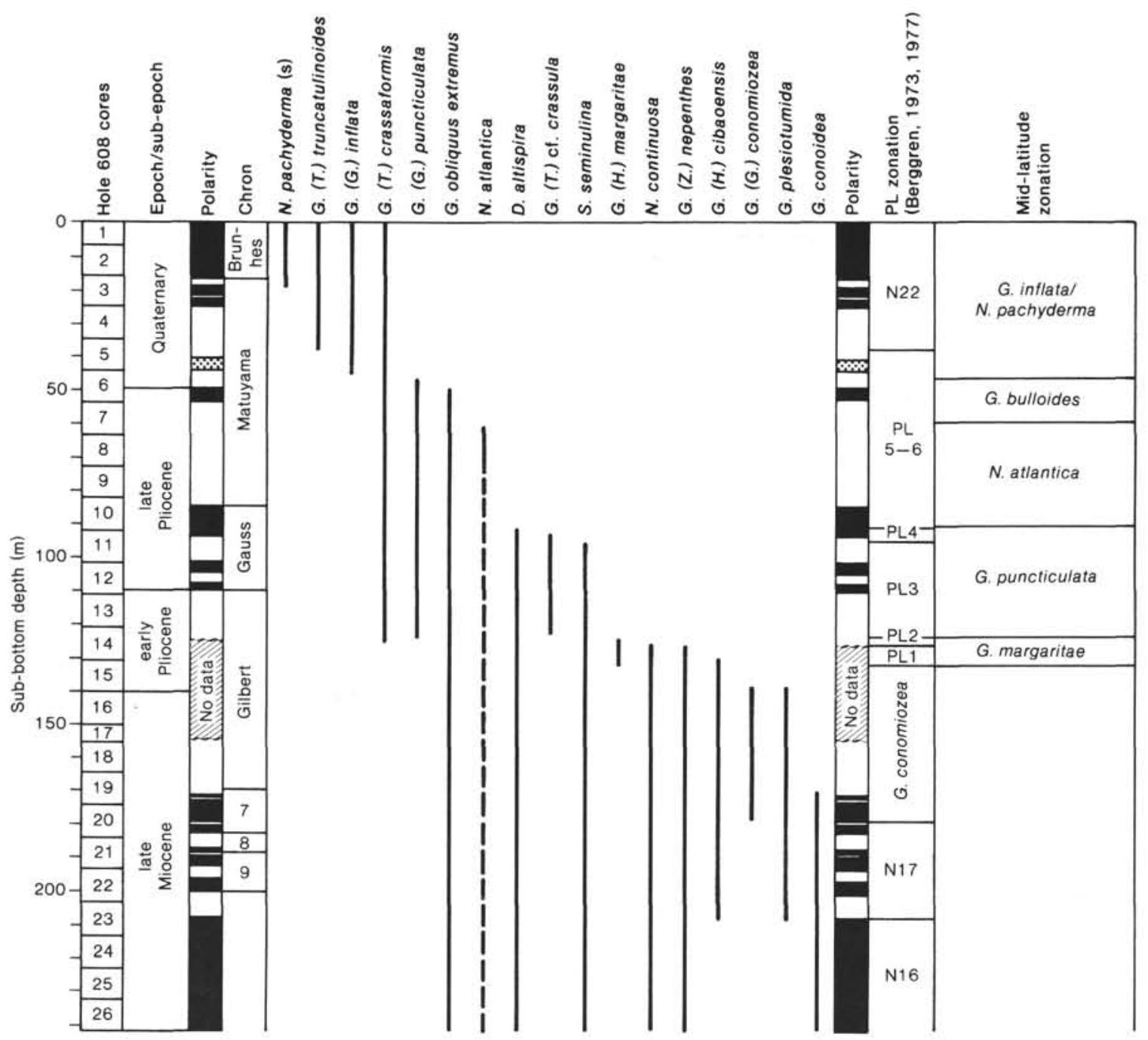

Figure 10. Magnetobiostratigraphy of Hole 608. Stipples mark alternative position of Olduvai Subchron.

locations for the Olduvai event at Site 608. The lower location (in Core 608-6), has a more coherent signal, but does not yield sensible correlations with planktonic foraminiferal datums or with calcareous nannofossil datums (Takayama and Sato, this volume). At Sites 606, 607 , and 609 to 611 , the transition from $G$. puncticulata to $G$. inflata occurs below the Olduvai, at $2.1 \mathrm{Ma}$. Even using the weaker (and higher) possible location of the Olduvai in Core $608-5$, we obtain an age of $1.9 \mathrm{Ma}$ for this datum. The ages of the LADs of $G$. puncticulata and $N$. atlantica are similarly too young by 0.2 to 0.3 m.y. In Hole 608A the situation is much worse: no reversals in the Matuyama make sense when correlated with the foraminiferal record (Fig. 11). The LAD of discoasters is in Core 608A-6 (Takayama and Sato, this volume), which should equate with the Olduvai (Haq et al., 1977). The nearest reversal, however, is at the base of Core 608-7. We therefore believe that much of Matuya$\mathrm{ma}$ is disturbed at this site. The reversal in Core 608-5 may represent the upper part of the Olduvai, but below this, to the base of the Matuyama, and in Hole 608A between Cores 608A- 6 and $608 \mathrm{~A}-10$, there appear to be a series of slumps and sediment disturbances.
Other, more obvious sediment disturbances occur in Cores 608-14 to 608-17, where the paleomagnetic record is extremely oscillatory. The foraminiferal data show a hiatus at the top of this interval, between the base of Sections 608-14-1 and 608-14-3. Because of the hiatus, most of the PL2 and PL1 zones are missing, as indicated by the very short range of $G$. margaritae. This hiatus does not occur in Hole 608A, which has a reasonable paleomagnetic record through this interval.

From Core 608-18 to Core 608-26 there appears to be a good paleomagnetic record of the late Miocene. Globorotalia conomiozea has its FAD in Core 608-19, at an estimated age of 6.5 to $7.0 \mathrm{Ma}$. Globorotalia plesiotumida is common down to Core 608-23, and its FAD has been used to define the N16/N17 zonal boundary. At Site 608 the age of this datum is 8.8 to $9.3 \mathrm{Ma}$. The FAD of $N$. acostaensis occurs in Core 608-26 and marks the middle/upper Miocene boundary.

\section{CONCLUSION}

Excepting Site 608, the Leg 94 sites provide excellent sections for magnetobiostratigraphy. High deposition rates and the absence of reworking, together with excellent 


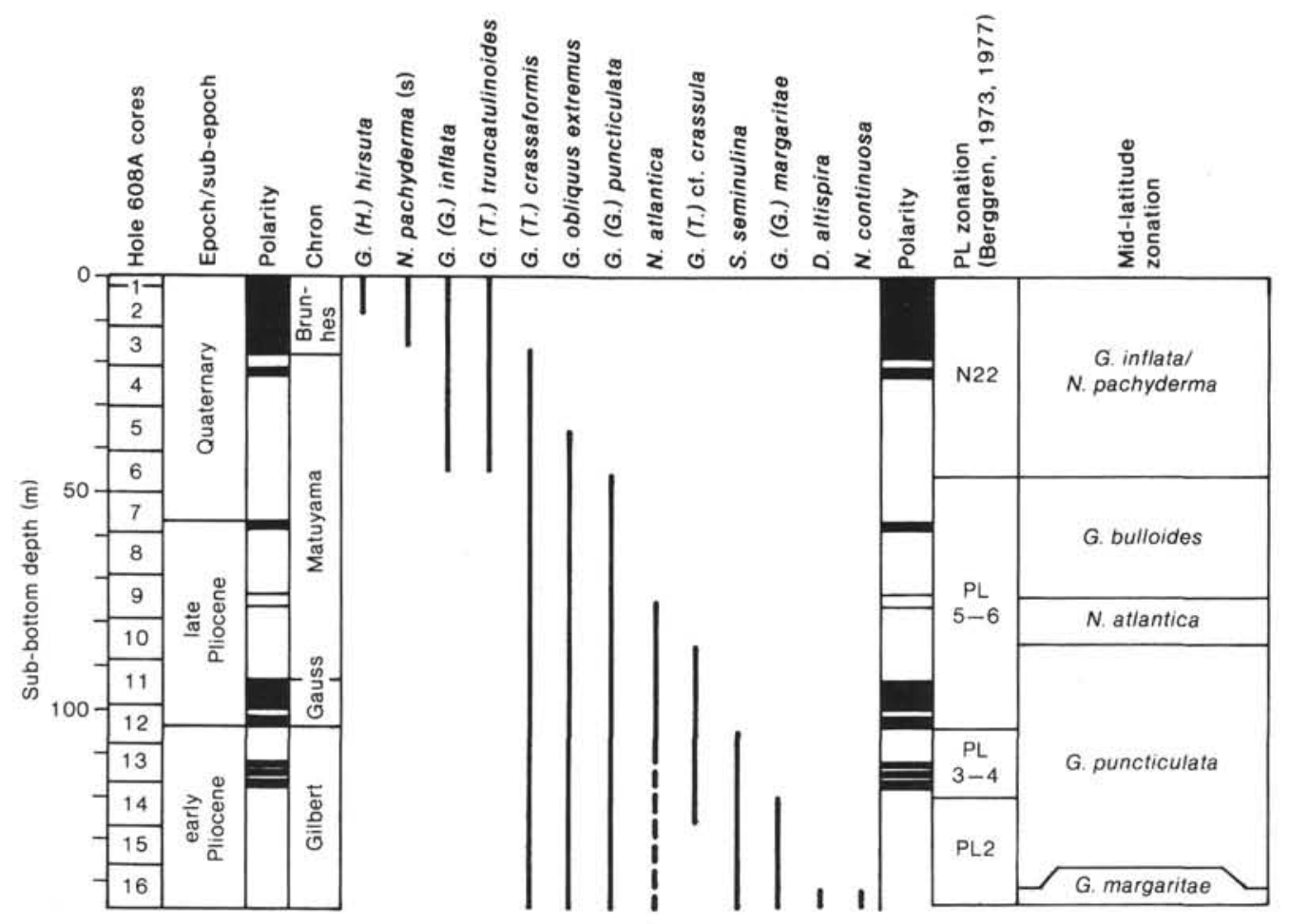

Figure 11. Magnetobiostratigraphy of Hole 608A.

paleomagnetic records, make possible age estimates of datums throughout the late Neogene. This south-north transect therefore provides a unique data set. We were able to compare the ages of datums across $15^{\circ}$ of latitude and to demonstrate synchrony and nonsychrony of first and last occurrences of planktonic foraminifera (Figs. 12,13 ) and determine the latitudinal extent of the distributions of some species.

Important findings emerge from testing Berggren's (1973, 1977) PL zonation of the Pliocene:

1. Latitudinal restrictions of zonal species. Globorotalia miocenica is not present north of $42^{\circ} \mathrm{N}$, Dentoglobigerina altispira and Sphaeroidinellopsis seminulina are rare at Site $608\left(43^{\circ} \mathrm{N}\right)$ and absent north of this.

2. Diachronic FADs and LADs. The LADs of Globorotalia margaritae and Globigerina nepenthes become progressively older in a northerly direction and are older at Site 606 than in tropical areas. The first appearance of Globorotalia truncatulinoides was later at Site 611 than at the other sites. At Sites 609, 610, and 611, this species has a sporadic distribution and is therefore of limited usefulness.

The recognition of Zones PL3 to PL6 is limited to subtropical areas, and recognition of Zones PL1 to PL3 is limited outside subtropical areas by diachronic datums.

Stratigraphically useful species can be recognized in the middle to high latitudes; these species make it possible to establish a zonation of the Pliocene (Weaver and Clement, in press). In this zonation, the LAD of Neogloboquadrina atlantica cannot be recognized south of $42^{\circ} \mathrm{N}$. Other datums, however, such as the FADs of Globorotalia puncticulata and Globorotalia inflata, can be recognized at all the sites. The FADs of both $G$. puncticulata and $G$. inflata are younger in the North Atlantic than in the South Pacific, and thus represent migrational events. Their ages are nevertheless synchronic across the North Atlantic.

We therefore caution against the indiscriminate use of micropaleontological datums for fine-scale global timestratigraphic correlations. Species may have different FADs and LADs in different oceans, and may in some cases show variations with latitude even in one ocean. We also advise against determining ages of datums in cores with low deposition rates or cores from areas with high dissolution rates.

\section{ACKNOWLEDGMENTS}

The authors would like to thank Dr. D. G. Jenkins for help and encouragement throughout this project. Drs. W. A. Berggren, J. P. Kennett, D. G. Jenkins, and C. Pujol kindly helped with some of the taxonomic problems, and Drs. W. A. Berggren and W. J. Zachariasse made helpful comments on the manuscript. Miss E. L. Woodward drafted the diagrams.

\section{REFERENCES}

Berger, W. H., and Heath, G. R., 1968. Vertical mixing in pelagic sediments. J. Mar. Res., 26:134-143.

Berggren, W. A., 1972. Cenozoic biostratigraphy and paleobiogeography of the North Atlantic. In Laughton, A. S., Berggren, W. A., et al., Init. Repts. DSDP, 12: Washington (U.S. Govt. Printing Office), 965-1001.

, 1973. The Pliocene time scale: Calibration of planktonic foraminiferal and calcareous nannoplankton zones. Nature, 243: 391-397.

1977. Late Neogene planktonic foraminiferal biostratigraphy of the Rio Grande Rise (South Atlantic). Mar. Micropaleontol., 2:265-313.

, 1984. Correlation of Atlantic Mediterranean and Indo-Pacific Neogene stratigraphies: Geochronology and chronostratigraphy. In Ikebe, N., and Tsuchi, R. (Eds.), Pacific Neogene Datum Planes. Contrib. Biostrat. Chronol. (Univ. Tokyo Press), pp. 29-60. 
Berggren, W. A., Aubrey, M. P., and Hamilton, N., 1983. Neogene magnetobiostratigraphy of Deep Sea Drilling Project Site 516 (Rio Grande Rise, South Atlantic). In Barker, P. F., Carlson, R. L., Johnson, D. A., et al., Init. Repts. DSDP, 72: Washington (U.S. Govt. Printing Office), 675-713.

Berggren, W. A., Kent, D. V., and Van Couvering, J. A., in press. Neogene geochronology and chronostratigraphy. In Snelling, N. J., (Ed.), Geochronology and the Geological Record. Geol. Soc. London Mem.

Blow, W. H., 1969. Late middle Eocene to Recent planktonic foraminiferal biostratigraphy. In Bronniman, P., and Renz, H. H. (Eds.), Proc. First Int. Conf. Plankt. Microfossils (Vol. 1): Leiden (E. J. Brill), 199-421.

Cita, M. B., 1973. Pliocene biostratigraphy and chronostratigraphy. In Ryan, W. B. F., Hsü, K. J., et al., Init. Repts. DSDP, 13, Pt. 2: Washington (U.S. Govt. Printing Office), 1343-1379. 1975. The Miocene/Pliocene boundary: History and definition. In Saito, T., and Burckle, L. (Eds.), Late Neogene Epoch Boundaries: New York (Micropaleo. Press), pp. 31-40.

Denham, C. R., and Chave, A. D., 1982. Detrital remanence magnetisation: Viscocity theory of the lock-in zone. J. Geophys. Res., 87: 7126-7130.

Dymond, J., 1969. Age determinations of deep-sea sediments: A comparison of three methods. Earth Planet. Sci. Lett., 6:9-14.

Haq, B. U., Berggren, W. A., and Van Couvering, J. A., 1977. Corrected age of the Pliocene/Pleistocene boundary. Nature, 269: 483-488.

Hays, J. D., Saito, T., Opdyke, N. D., and Burkle, L. H., 1969. Pliocene-Pleistocene sediments of the equatorial Pacific: Their paleomagnetic biostratigraphic and climatic record. Geol. Soc. Am. Bull., 80:1481-1514.

Hooper, P. W. P., and Funnell, B. M., in press. Late Pliocene to Recent planktonic foraminifera from the North Atlantic: Quantitative palaeotemperature analysis. In Summerhayes, C. P., and Shackleton, N. J. (Eds.), North Atlantic Paleoceanography. Spec. Publ.Geol. Soc. London.

Hooper, P. W. P., and Weaver, P. P. E., in press. Late Neogene species of the genus Neogloboquadrina in the North Atlantic: A biostratigraphic, palaeoceanographic and phylogenetic review. In Hart, M. B. (Ed.), The Micropalaeontology of Carbonate Environments: Chichester (Ellis Horwood).

Huddlestun, P. F., 1984. Planktonic foraminiferal biostratigraphy of the Hatton-Rockall Basin: DSDP Leg 81, In Roberts D. A., Schnitker, D., et al., Init. Repts. DSDP, 81: Washington (U.S. Govt. Printing Office), 429-438.

Keigwin, L. D., 1982. Appendix: Basis for age assignment at Deep Sea Drilling Project Sites 502 and 503. In Prell, W. L., Gardner, J. V., et al., Init. Repts. DSDP, 68: Washington (U.S. Govt. Printing Office), 493-495.

Keller, G., 1979. Early Pliocene to Pleistocene planktonic foraminiferal datum levels in the North Pacific. DSDP Sites 173, 310, 296. Mar. Micropaleontol., 4:281-294.

Kennett, J. P., 1968. Globorotalia truncatulinoides as a paleo-oceanographic index. Science, 159:1461-1463.

1973. Middle and late Cenozoic planktonic foraminiferal biostratigraphy of the southwest Pacific-DSDP Leg 21. In Burns, R. E., Andrews, J. E., et al., Init. Repts. DSDP, 21: Washington (U.S. Govt. Printing Office), 575-639.

Kennett, J. P., and Srinivasan, M. S., 1983. Neogene Planktonic Foraminifera: Stroudsburg, Pa. (Hutchinson Ross).

Kennett, J. P., and Watkins, N. D., 1974. Late Miocene-early Pliocene paleomagnetic stratigraphy paleoclimatology and biostratigraphy in New Zealand. Geol. Soc. Am. Bull., 85:1385-1398.

LaBrecque, J. L., Kent, D. V., and Cande, S. C., 1977. Revised magnetic polarity time-scale for the late Cretaceous and Cenozoic time. Geology, 5:330-335.

Malmgren, B. A., and Kennett, J. P., 1982. The potential of morphometrically based phylo-zonation. Application of a late Cenozoic planktonic foraminiferal lineage. Mar. Micropaleontol., 7:285-296.
Mankinen, E. A., and Dalrymple, G. B., 1979. Revised geomagnetic polarity time-scale for the interval 0-5 m.y. B. P. J. Geophys. Res., 84:615-626.

Mazzei, R., Raffi, I., Rio, D., Hamilton, N., and Cita, M. B., 1979. Calibration of late Neogene calcareous plankton datum planes with the paleomagnetic record of Site 397 and correlation with Moroccan and Mediterranean sections. In von Rad, U., Ryan, W. B. F., et al., Init. Repts. DSDP , 47, Pt. 1: Washington (U.S. Govt. Printing Office), 375-389.

Miles, G. A., 1977. Planktonic foraminifera from Leg 37 of the Deep Sea Drilling Project. In Aumento, F., Melson, W. G., et al., Init. Repts. DSDP, 37: Washington (U.S. Govt. Printing Office), 929961.

Otofuji, Y., and Sasjima, S., 1981. A magnetisation process of sediments: Laboratory experiments on PDRM. Geophys. J. R. Astron. Soc., 66:241-259.

Poore, R. Z., 1979. Oligocene through Quaternary planktonic foraminiferal biostratigraphy of the North Atlantic, DSDP Leg 49. In Luyendyk, B. P., Cann, J. R., et al., Init. Repts. DSDP, 49: Washington (U.S. Govt. Printing Office), 447-517.

Poore, R. Z., Berggren, W. A., 1975. Late Cenozoic planktonic foraminiferal biostratigraphy and paleoclimatology of Hatton-Rockall Basin DSDP Site 116. J. Foram. Res., 5:270-293.

Poore, R. Z., Tauxe, L., Percival, S. F., LaBrecque, J. L., Wright, R., et al., 1984. Late Cretaceous-Cenozoic magnetostratigraphic and biostratigraphic correlations for the South Atlantic Ocean, Deep Sea Drilling Project Leg 73. In Hsü, K. J., LaBrecque, J. L., et al., Init. Repts. DSDP, 73: Washington (U.S. Govt. Printing Office), 645-655.

Pujol, C., and Duprat, J., 1985. Quaternary and Pliocene planktonic foraminifers of the northeastern Atlantic (Goban Spur), DSDP Leg 80. In Graciansky, P. C. de, Poag, C. W., et al., Init. Repts. DSDP, 80: Washington (U.S. Govt. Printing Office), 683-723.

Rio, D., Sprovieri, R., and Raffi, I., 1984. Calcareous plankton biostratigraphy and biochronology of the Pliocene-lower Pleistocene succession of the Capo Rossello area, Sicily. Mar. Micropaleontol., 9:135-180.

Ruddiman, W. F., and Glover, L. K., 1972. Vertical mixing of ice-rafted volcanic ash in North Atlantic sediments. Geol. Soc. Am. Bull., 83:2817-2836.

Ryan, W. B. F., 1973. Paleomagnetic stratigraphy. In Ryan, W. B. F., Hsü, K. J., et al., Init. Repts. DSDP, 13, Pt. 2: Washington (U.S. Govt. Printing Office), 1380-1387.

Ryan, W. B. F., Cita, M. B., Rawson, M. D., Burckle, L. H., and Saito, T., 1974. A palaeomagnetic assignment of Neogene stage boundaries and the development of isochronous datum planes between the Mediterranean, the Pacific and Indian oceans in order to investigate the response of the world ocean to the Mediterranean "salinity crisis." Riv. Ital. Paleontol., 80:631-688.

Saito, T., Burckle, L. H., and Hays, J. D., 1975. Late Miocene to Pleistocene biostratigraphy of equatorial Pacific sediments. In Saito, T., and Burckle, L. (Eds.), Late Neogene Epoch Boundaries: New York (Micropaleo. Press), pp. 226-244.

Spaak, P., 1983. Accuracy in correlation and ecological aspects of the planktonic foraminiferal zonation of the Mediterranean Pliocene. Utrecht Micropal. Bull., 28:160.

Tucker, P., 1980. A grain mobility model of postdepositional realignment. Geophys, J. R. Astron. Soc., 63:149-163.

Watkins, N. D., 1968. Short period geomagnetic polarity events in deep-sea sedimentary cores. Earth Planet. Sci. Lett., 4:341-349.

Weaver, P. P. E., and Clement, B. M., in press. Synchroneity of Pliocene planktonic foraminiferal datums in the North Atlantic. Mar. Micropaleontol.

Date of Initial Receipt: 25 June 1985

Date of Acceptance: 28 January 1986 


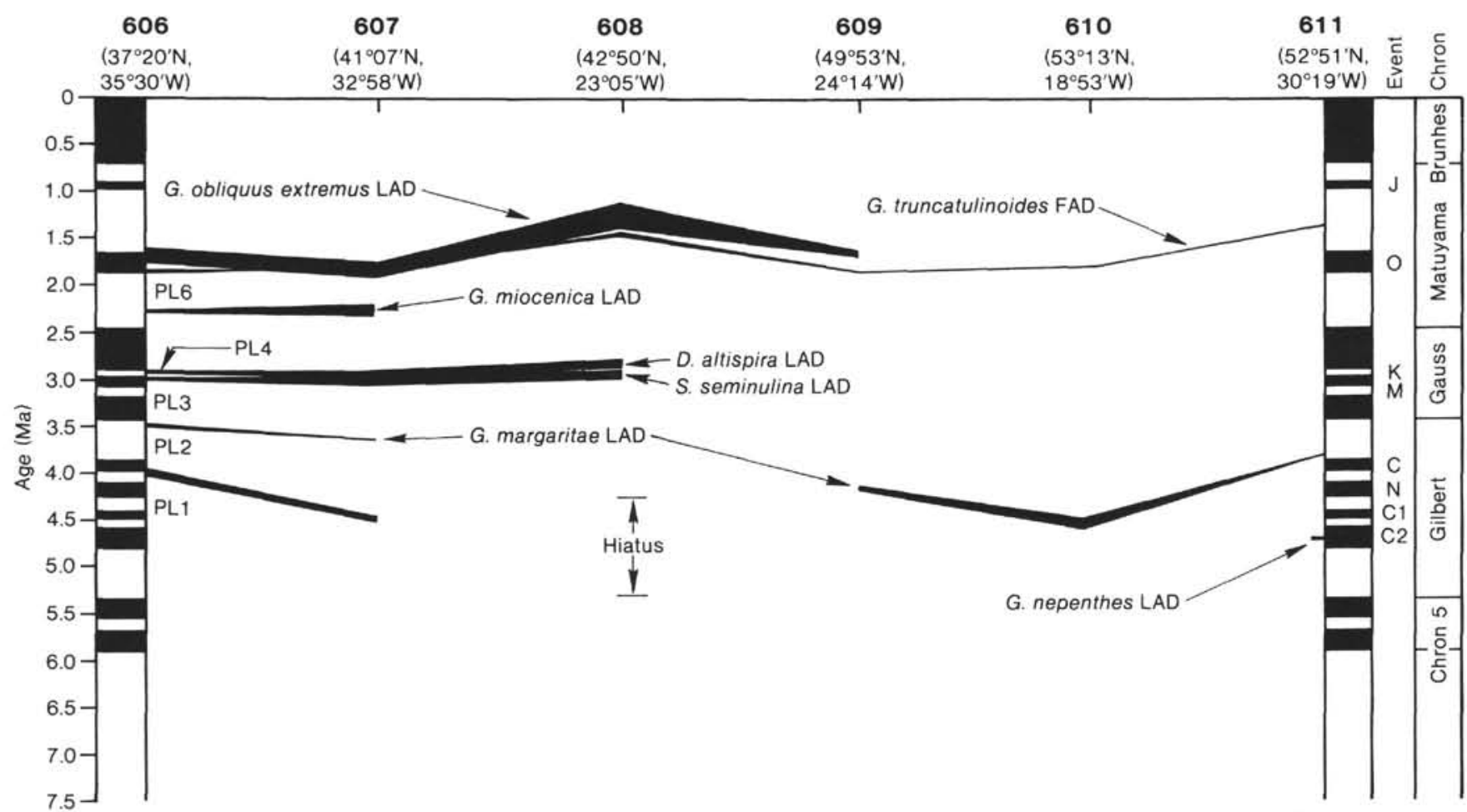

Figure 12. Comparison of ages of PL zonal markers at Leg 94 sites. See Figure 4 caption for identification of magnetic events letter designations.

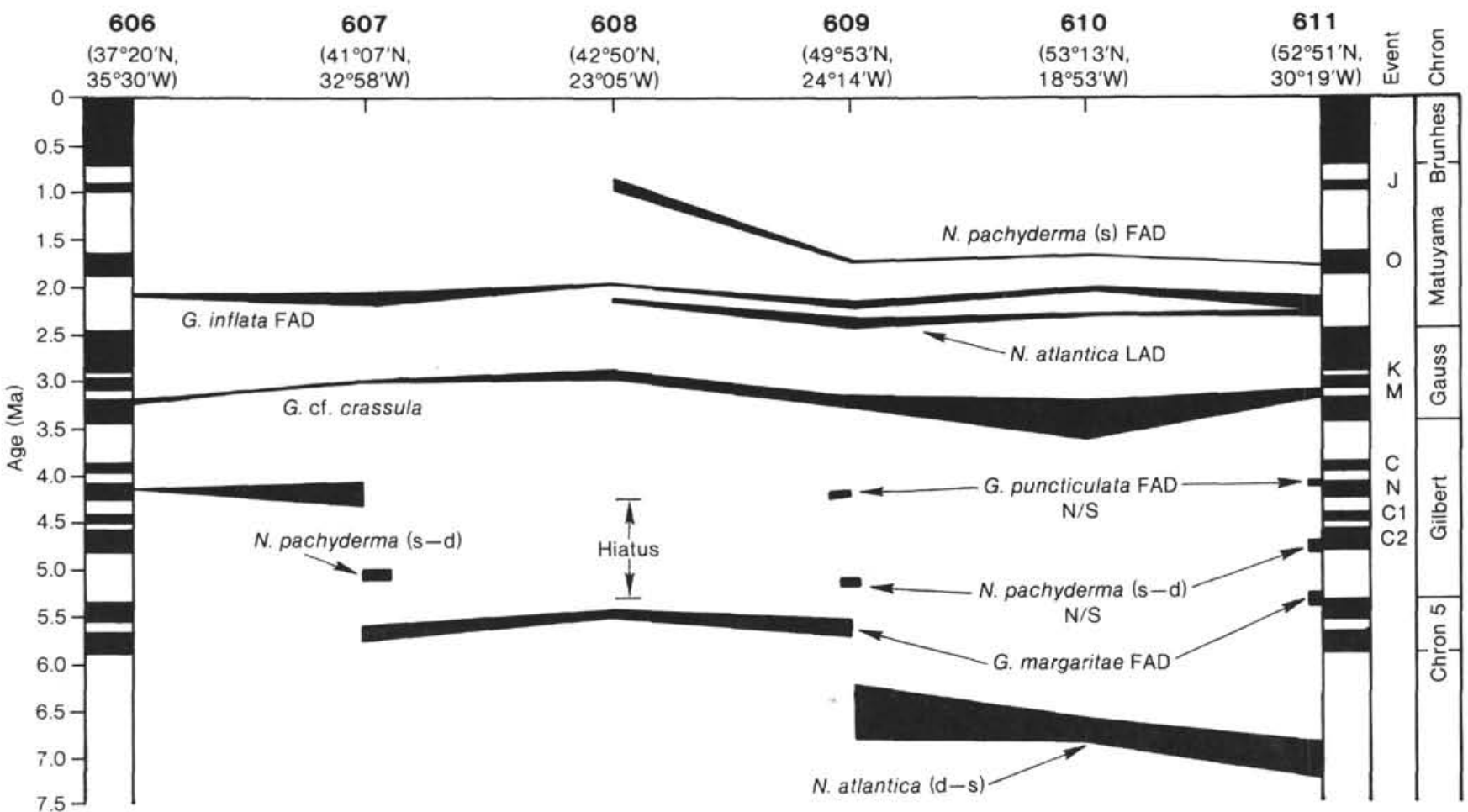

Figure 13. Comparison of ages of stratigraphically useful planktonic foraminiferal datums. (N/S = not sampled.) See Figure 4 caption for identification of magnetic events. 